\title{
Keterampilan Berpikir Kritis Pada Bounded Inquiry Lab: Analisis
}

\section{Kuantitatif dan Kualitatif}

\author{
Anisak Intan Eka Prani*, Parno, Arif Hidayat \\ Universitas Negeri Malang, Jl. Semarang no. 55 Malang \\ *Penulis korespondensi, e-mail: intananisa94@yahoo.co.id
}

\begin{abstract}
Critical thinking skills as an important skill in the 21st century is a major goal of science education. Therefore the researchers develop various learning strategies to enhance and develop students' critical thinking skills. They develop learning materials that integrated with ability to think critically. However, the strategy makes students less understand to the concept of the material. Learning strategy as bounded inquiry lab model can improve both critical thinking skill and students' comprehension of the material. This study aims to determine effectiveness of bounded inquiry lab to critical thinking skills in high school students. This study focuses on hydrostatic pressure, Pascal's law, and Archimedes' law. Mixed methods of embedded model design were used during the study. A total of 30 students in major natural science program undergo pre test, followed by learning using bounded inquiry lab, doing post test and then interview. The results showed that students' critical thinking skills on hydrostatic pressure, Pascal's law, and Archimedes' law increased from an average of 20.00 in pretest to 80.67 in post test. In addition, students said that they can improve their understand concepts of matter, determine the variables, how to create and test hypotheses through scientific work, and make good conclusion through classroom learning. So, bounded inquiry lab should be used as an alternative learning to enhance critical thinking skills in static fluids.
\end{abstract}

Key Words:bounded inquiry lab; critical thinking skills

\begin{abstract}
Abstrak: Keterampilan berpikir kritis sebagai keterampilan penting di abad 21 merupakan tujuan utama pendidikan sains. Hal tersebut membuat para peneliti mengembangkan berbagai strategi pembelajaran untuk mengembangkan keterampilan berpikir kritis siswa. Sebagian besar peneliti mengembangkan keterampilan berpikir kritis yang terintegrasi dengan materi pembelajaran. Namun, strategi tersebut membuat siswa kurang memahami konsep dari materi. Strategi pembelajaran berupa model bounded inquiry lab merupakan salah satu model yang dapat meningkatkan keterampilan berpikir kritis sekaligus meningkatkan pemahaman siswa pada materi. Penelitian ini bertujuan mengetahui efektivitas bounded inquiry lab terhadap keterampilan berpikir kritis siswa SMA. Penelitian ini berfokus pada materi tekanan hidrostatis, hukum Pascal, dan hukum Archimedes. Mixed methods desain embedded model digunakan selama penelitian. Sebanyak 30 siswa kelas XI IPA SMA menjalani pre test, dilanjutkan dengan pembelajaran menggunakan bounded inquiry lab, mengerjakan soal post test kemudian wawancara. Hasil penelitian menunjukkan bahwa keterampilan berpikir kritis siswa pada materi tekanan hidrostatis, hukum Pascal, dan hukum Archimedes meningkat dari rata-rata nilai pre test sebesar 20,00 ke nilai post test sebesar 80,67. Di samping itu, menurut siswa, pembelajaran di kelas membuat mereka lebih memahami konsep materi, menentukan variabel, cara membuat dan menguji hipotesis melalui kerja ilmiah, serta membuat kesimpulan dengan baik. Berdasarkan hasil penelitian, bounded inquiry lab dapat digunakan sebagai salah satu alternatif strategi pembelajaran untuk meningkatkan keterampilan berpikir kritis siswa pada materi fluida statis.
\end{abstract}

Kata kunci: bounded inquiry lab; keterampilan berpikir kritis

How to Cite:

Prani, A., Parno, P., \& Hidayat, A. (2018). Keterampilan berpikir kritis pada Bounded Inquiry Lab: analisis kuantitatif dan kualitatif. Momentum: Physics Education Journal, 2(1).

https://doi.org/10.21067/mpej.v1i1.2217

This is an open access article under the CC BY license (http://creativecommons.org/licenses/by-nc-nd/4.0/) https://doi.org/10.21067/mpej.v1i1.2217 


\section{Pendahuluan}

Mengembangkan keterampilan berpikir kritis sebagai keterampilan penting yang diperlukan di abad 21 merupakan tujuan utama pendidikan sains (Ku, Ho, \& Eva, 2014; Piergiovanni \& Piergiovanni, 2014a; Tiruneh, Verburgh, \& Elen, 2014; Dawit Tibebu Tiruneh et al., 2016; Dawit Tibebu Tiruneh \& Cock, 2017; Holmes, 2017). Keterampilan berpikir kritis meliputi keterampilan untuk menganalisis kemungkinan, membuat prediksi dan keputusan logis, menyelesaikan masalah kompleks, membuat kesimpulan valid, dan mengidentifikasi hubungan (Halpern, 2014; Dawit Tibebu Tiruneh \& Cock, 2017). Kecakapan siswa dalam berpikir kritis membuat siswa berhasil mengikuti pembelajaran sains dengan baik (Ramsey \& Baethe, 2013; Dawit Tibebu Tiruneh et al., 2016), menyelesaikan masalah dan tantangan di masa sekarang dan masa mendatang (Dwyer, Hogan, \& Stewart, 2012; Dawit T Tiruneh et al., 2014), serta menjadi masyarakat yang aktif dan informatif (Butler et al., 2012; Halpern, 2014).

Meskipun keterampilan berpikir kritis merupakan salah satu keterampilan yang dibutuhkan, keterampilan berpikir kritis siswa masih tergolong rendah (Arum \& Roksa, 2011) sehingga beberapa peneliti mulai fokus untuk mengidentifikasi strategi pembelajaran yang efektif untuk mengembangkan keterampilan berpikir kritis. Beberapatahun yang lalu, keterampilan berpikir kritis dilatihkan secara terpisah dari materi pembelajaran (general approach) sehingga tingkat keterampilan berpikir kritis pada suatu materi pelajaran tidak dapat ditentukan (Pascarella, 2016). Hal itu menyebabkan strategi ini telah ditinggalkan dan peneliti mulai melakukan penelitian tentang strategi pembelajaran dengan melatihkan keterampilan berpikir kritis yang terintegrasi dengan materi pembelajaran (infusion, immersion, dan mixed approach).

Pendekatan infusi (infusion approach) merupakan pendekatan yang secara eksplisit mengintegrasikan keterampilan berpikir kritis pada materi pembelajaran (Dawit T Tiruneh et al., 2014) sehingga siswa dapat meningkatkan keterampilan berpikir kritis sekaligus mempelajari materi pembelajaran dengan baik. Pendekatan immersi (immersion approach) juga mengintegrasikan keterampilan berpikir kritis pada materi pembelajaran. Namun prinsip dan prosedurnya tidak diajarkan secara eksplisit dengan asumsi siswa akan memperoleh keterampilan berpikir kritis setelah mengikuti pembelajaran yang terintegrasi dengan keterampilan berpikir kritis (Dawit T Tiruneh et al., 2014). Pendekatan campuran (mixed approach) merupakan kombinasi dari pendekatan infusi dan imersi (Dawit T Tiruneh et al., 2014).

Berdasarkan tiga pendekatan tersebut, pendekatan infusi merupakan pendekatan yang paling berhasil meningkatkan keterampilan berpikir kritis (Anderson, Howe, Soden, \& Low, 2001; Mazer, 2007; Angeli \& Valanides, 2009; Bensley et al., 2010). Hal ini dikarenakan mengintegrasikan keterampilan berpikir kritis secara eksplisit pada pembelajaran dapat memupuk keterampilan berpikir kritis sehingga siswa dapat menyelesaikan tugas dengan berbagai macam variasi pertanyaan (domain specific critical thinking) dan menyelesaikan masalah lain pada kehidupan sehari-hari (domain general critical thinking) (Preiss \& Sternberg, 2010; Dawit T Tiruneh et al., 2014). Hasil analisis Tinureh, et al (2016) menyatakan beberapa penelitian menunjukkan bahwa siswa yang dapat menyelesaikan tugas dengan berbagai variasi pertanyaan (domain specific critical thinking) dapat menyelesaikan permasalahan pada kehidupan sehari-hari dengan efektif (Solon, 2007; Dwyer et al., 2012; Bensley \& Spero, 2014). Walaupun beberapa penelitian menunjukkan hasil yang tidak signifikan (Anderson et al., 2001; Mclean \& Miller, 2010; Toy \& Ok, 2012).

Hal tersebut menyebabkan pengembangan keterampilan berpikir kritis melalui pendekatan infusi telah banyak dilakukan. Alwehaibi (2012) menggunakan strategi direct instruction dengan pemodelan guru dan melakukan diskusi dari contoh-contoh fenomena di kehidupan nyata untuk mengembangkan keterampilan berpikir kritis. Hasil penelitian menunjukkan bahwa strategi ini dapat meningkatkan keterampilan berpikir kritis secara signifikan. Strategi mengajar dengan bantuan scaffolding, pemberian latihan dan umpan balik (Yeh, 2009; Bensley et al., 2010; Alwehaibi et al., 2012), pemberian refleksi, 
evaluasi berpasangan (Angeli \& Valanides, 2009), pemberian pertanyaan yang memenuhi kriteria berpikir tingkat tinggi (Barnett \& Francis, 2012; Renaud \& Murray, 2008), serta melalui pemberian masalah yang kontekstual (Odabas, 2009) juga telah berhasil meningkatkan keterampilan berpikir kritis.

Walaupun banyak hasil penelitian yang menyebutkan bahwa strategi pembelajaran langsung yang terintegrasi dengan materi dapat meningkatkan keterampilan berpikir kritis, dampak dari desain tersebut telah diabaikan. Strategi tersebut cenderung hanya meningkatkan keterampilan berpikir kritis dan kurang mengoptimalkan esensi materi pembelajaran (Dawit T Tiruneh et al., 2014; Dawit Tibebu Tiruneh et al., 2016). Perlu dilakukan penelitian tentang strategi pembelajaran yang cocok untuk meningkatkan keterampilan berpikir kritis tanpa mengabaikan esensi dari materi pembelajaran yang sedang dipelajari sehingga domain umum dan khusus dari berpikir kritis tetap diperoleh siswa. Strategi pembelajaran ini dapat berupa model pembelajaran yang dapat memfasilitasi siswa untuk belajar secara aktif (Lasry, Charles, \& Whittaker, 2014) dan dapat membangun konsep yang benar (Young, College, \& Peter, 2017) sehingga didapatkan hasil belajar yang baik (Merrill, 2013 ; Dawit Tibebu Tiruneh et al., 2016).

Salah satu model pembelajaran yang dapat memenuhi standar tersebut adalah bounded inquiry lab . Bounded inquiry lab merupakan tingkatan keempat pada levels of inquiry models of science teaching yang memfasilitasi siswa untuk belajar secara aktif melalui tahapan observasi, manipulasi, generalisasi, verifikasi, dan aplikasi (Wenning, 2011). Tujuan dari penelitian ini adalah untuk mengetahui keefektifan model pembelajaran bounded inquiry lab dalam mengembangkan keterampilan berpikir kritis pada domain khusus dan umum materi fluida statis.

\section{Metode}

Penelitian ini menggunakan mixed methods desain embedded experimentalmodel (Creswell dan Clark, 2007). Penelitian diawali dengan pemberian pretest untuk mengetahui keterampilan berpikir kritis awal siswa. Tahap kedua adalah pemberian perlakuan berupa pembelajaran materi tekanan hidrostatis, hukum Pascal, dan hukum Archimedes yang diajarkan dengan model pembelajaran bounded inquiry lab. Selama kegiatan pembelajaran, dilakukan pengamatan oleh observer untuk mengetahui data keterlaksanaan pembelajaran dan keterampilan yang dilakukan siswa. Setelah kegiatan pembelajaran selesai dilaksanakan, dilakukan posttest dan kemudian wawancara. Nilai hasil posttest dianalisis secara kuantitatif dan kualitatif untuk melihat peningkatan keterampilan berpikir kritis siswa.

Subyek penelitian adalah siswa SMA IPA kelas XI tahun ajaran 2017/ 2018 sebanyak 30 orang dengan 18 orang siswa perempuan dan 12 siswa laki-laki di SMAN 2 Batu. Pemilihan sampel dilakukan dengan cara purposive sampling untuk mendapatkan satu kelas dengan kemampuan yang homogen. Subjek penelitian menerima perlakuan pada materi tekanan hidrostatis, hukum Pascal, dan hukum Archimedes karena berdasarkan hasil studi awal menunjukkan bahwa nilai keterampilan berpikir kritis pada ketiga sub materi tersebut tergolong rendah. Perlakuan diberikan selama tiga kali pertemuan dengan waktu 90 menit pada masing-masing pertemuan. Subyek penelitian diberikan soal yang sama pada pretest dan posttest. Soal pretest dan posttest terdiri dari lima soal pilihan ganda.

Pemberian perlakukan kepada siswa digunakan untuk melatihkan dan meningkatkan keterampilan berpikir kritis siswa yang meliputi keterampilan untuk bernalar, menganalisis argumen, menguji hipotesis, menganalisis kemungkinan dan ketidakpastian, serta membuat keputusan dan menyelesaikan masalah kompleks. Setelah komponen keterampilan berpikir kritis yang akan dilatihkan telah teridentifikasi, dilakukan desain pembelajaran yang sesuai untuk mengembangkan masing-masing keterampilan. Tabel 1 menyajikan tahapan pembelajaran yang telah dilakukan, implikasi pada perilaku siswa selama pembelajaran, dan komponen keterampilan berpikir kritis yang dilatihkan.

Data hasil pretest dan posttest diuji menggunakan paired sample t-test untuk mengetahui ada atau tidaknya perbedaan antara nilai pretest dan posttest. Perhitungan untuk deskripsi statistik dan paired sample t-test menggunakan program SPSS Statistic 17.0 for Windows.Setelah itu menghitung rata-rata gain 
ternormalisasi <g> dan effect size menggunakan Microsoft Excel 2007. Analisis kualitatif dilakukan dengan cara reduksi data, pengkodean, penyajian data, dan penarikan kesimpulan berdasarkan hasil observasi dan wawancara.

Tabel 1. Instrumen Pembelajaran

\begin{tabular}{|c|c|c|}
\hline $\begin{array}{l}\text { Tahapan bounded } \\
\text { inquiry lab }\end{array}$ & Implikasi pada perilaku siswa di pembelajaran & $\begin{array}{c}\text { Komponen keterampilan berpikir } \\
\text { kritis yang dilatihkan }\end{array}$ \\
\hline Observasi & $\begin{array}{l}\text { 1. Mengamati tayangan apersepsi dan } \\
\text { atau demonstrasi yang berkaitan } \\
\text { dengan materi } \\
\text { 2. Mengajukan pertanyaan terkait video } \\
\text { dan atau demonstrasi }\end{array}$ & $\begin{array}{l}\text { 1. Keterampilan untuk } \\
\text { bernalar melalui } \\
\text { pengajuan pertanyaan }\end{array}$ \\
\hline Manipulasi & $\begin{array}{l}\text { 1. Mendiskusikan rumusan masalah } \\
\text { dengan teman sekelompok } \\
\text { 2. Menuliskan hipotesis } \\
\text { 3. Mengidentifikasi variabel kontrol, } \\
\text { bebas, dan terikat pada percobaan } \\
\text { 4. Mendiskusikan rancangan percobaan } \\
\text { 5. Melakukan praktikum }\end{array}$ & $\begin{array}{l}\text { 1. Kemampuan untuk } \\
\text { bernalar } \\
\text { 2. Membuat hipotesis untuk } \\
\text { diuji }\end{array}$ \\
\hline Generalisasi & $\begin{array}{l}\text { 1. Mempresentasikan hasil percobaan } \\
\text { 2. Memberikan pendapat dan koreksi } \\
\text { 3. Membangun prinsip hubungan } \\
\text { kesebandingan } \\
\text { 4. Melakukan analisis dimensi } \\
\text { 5. Mengerjakan soal latihan }\end{array}$ & $\begin{array}{l}\text { 1. Menganalisis argumen } \\
\text { 2. Keterampilan untuk } \\
\text { bernalar } \\
\text { 3. Menyelesaikan masalah } \\
\text { kompleks }\end{array}$ \\
\hline Verifikasi & $\begin{array}{l}\text { 1. Melakukan pengecekan kebenaran } \\
\text { rumusan }\end{array}$ & $\begin{array}{l}\text { 1. Kemampuan untuk } \\
\text { bernalar } \\
\text { 2. Menganalisis argumen }\end{array}$ \\
\hline Aplikasi & $\begin{array}{l}\text { 1. Membuat dan menyepakati } \\
\text { kesimpulan } \\
\text { 2. Membahas pertanyaan di awal } \\
\text { pembelajaran } \\
\text { 3. Menerapkan konsep di video dan atau } \\
\text { demonstrasi apersepsi } \\
\text { 4. Menyebutkan penerapan konsep lain } \\
\text { di kehidupan }\end{array}$ & \\
\hline
\end{tabular}

\section{Hasil dan Pembahasan}

Observasi pada pembelajaran dilakukan untuk mengetahui tingkat keterlaksanaan pembelajarannya. Keterlaksanaan pembelajaran guru dan siswa disajikan pada Tabel 2. Berdasarkan Tabel 2 dapat diketahui bahwa pembelajaran di kelas terlaksana dengan sangat baik. Hal ini dibuktikan dengan persentase keterlaksanaan pembelajaran selalu diatas $80 \%$ di setiap pertemuan.

Hasil jawaban benar dari soal keterampilan berpikir kritis pada pretest dan posttest disajikan pada Gambar 1.

Tabel 2. Keterlaksanaan Pembelajaran

\begin{tabular}{lcccccc}
\hline & \multicolumn{7}{c}{ Pertemuan ke- } \\
\cline { 2 - 8 } & Guru & Siswa & Guru & Siswa & Guru & Siswa \\
\cline { 2 - 8 } & 15 & 20 & 15 & 23 & 15 & 23 \\
\hline $\begin{array}{l}\text { Skor } \\
\text { maks }\end{array}$ & 16 & 25 & 16 & 25 & 16 & 25 \\
\hline$\%$ & 93,75 & 80 & 93,75 & 92 & 93,75 & 92 \\
\hline
\end{tabular}




\begin{tabular}{lllllll}
\hline Kriteria & SB & SB & SB & SB & SB & SB \\
\hline
\end{tabular}

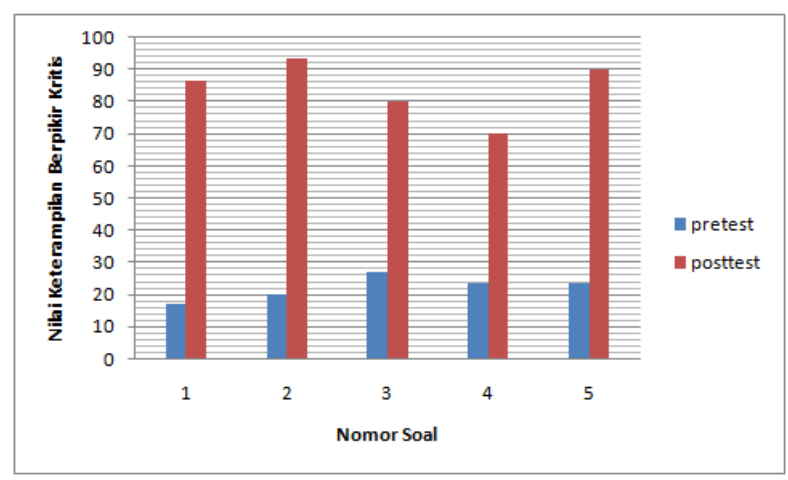

Gambar 1. Nilai keterampilan berpikir kritis pada pretest dan posttest

Berdasarkan grafik pada Gambar 1 dapat diketahui bahwa terdapat peningkatan nilai keterampilan berpikir kritis dari nilai pretest ke nilai posttest. Pada soal nomor 1, terdapat 5 siswa (16,67\%) menjawab benar pada pretest dan 26 siswa (86,67\%) menjawab benar pada posttest. Hasil keterampilan berpikir kritis kriteria menguji hipotesis pada nomor 2 menunjukkan hasil 6 siswa (20\%) menjawab benar pada pretest dan 28 siswa $(93,33 \%)$ menjawab benar pada posttest. Soal nomor 3 yang digunakan untuk mengukur keterampilan berpikir kritis pada kriteria menganalisis argumen menunjukkan hasil 8 siswa (26,67 \%) menjawab benar saat pretest dan 24 siswa $(80,00 \%)$ menjawab benar saat posttest. Soal nomor 4 yang digunakan untuk mengukur keterampilan berpikir kritis pada kriteria menyelesaikan masalah kompleks menunjukkan hasil 7(23,33\%) siswa yang menjawab benar saat pretestdan 21 siswa (70,00 \%) menjawab benar pada saat posttest. Hasil keterampilan berpikir kritis pada kriteria menganalisis kemungkinan dan ketidakpastian menunjukkan hasil 7 siswa (23,33 \%) menjawab benar saat pretest dan 27 siswa (90,00 \%) menjawab benar saat posttest.

Hasil tersebut menggambarkan bahwa model pembelajaran bounded inquiry lab berhasil untuk meningkatkan keterampilan berpikir kritis pada kriteria kemampuan untuk bernalar, menguji hipotesis, menganalisis argumen, menyelesaikan masalah kompleks, serta menganalisis kemungkinan dan ketidakpastian. Hal ini sesuai dengan hasil penelitian (Wenning, 2010; Wenning, 2011) yang menyebutkan siswa yang melakukan kolaborasi secara aktif dan melakukan langkah-langkah ilmiah di dalam kelas, dapat meningkatkan keterampilan intelektual dan keterampilan proses mereka. Halpern (2014) juga menyebutkan bahwa keterampilan berpikir, sikap ilmiah, serta pengetahuan akan menjadikan siswa mempunyai keterampilan berpikir kritis. Langkah-langkah bounded inquiry lab mulai observasi hingga aplikasi menuntut siswa untuk aktif bekerja secara kolaboratif dan membangun konsepnya berdasarkan kerja ilmiah (Wenning, 2011) sehingga dapat melatihkan keterampilan berpikir kritis siswa selama pembelajaran.

Keterampilan berpikir kritis kriteria kemampuan untuk bernalar, menguji hipotesis, menganalisis argumen, serta menganalisis kemungkinan dan ketidakpastian memperoleh nilai tinggi yaitu diatas $80,00 \%$. Berdasarkan hasil wawancara, mereka dapat mengembangkan keterampilan bernalar karena pada saat pembelajaran, siswa difasilitasi untuk melakukan observasi terhadap fenomena-fenomena terkait materi yang dapat mempengaruhi pemikiran siswa untuk bernalar (Wenning, 2011). Keterampilan menguji hipotesis siswa juga didapatkan nilai yang tergolong tinggi yaitu 93,33\%. Selama tahap pembelajaran bounded inquiry lab, siswa dibimbing untuk menentukan variabel, hubungan antar variabel, membuat hipotesis, dan prosedur ilmiah untuk menguji hipotesis (Wenning, 2010; Wenning, 2011) sehingga siswa dapat meningkatkan keterampilan menguji hipotesisnya. Menganalisis argumen juga mendapatkan nilai yang tinggi karena siswa dibimbing untuk menyediakan alasan yang bisa mendukung ataupun menolak suatu kesimpulan seseorang (Halpern, 2014). Hal ini bisa ditemui pada saat kegiatan presentasi. Selama 
pembelajaran, siswa diberikan pengetahuan mengenai perbedaan kesimpulan dan asumsi yang dapat mereka gunakan untuk menganalisis argumen. Siswa juga berpendapat bahwa mereka dibimbing untuk menganalisis kemungkinan dan ketidakpastian selama pembelajaran melalui tahap merancang percobaan.

Hal yang sedikit berbeda ditunjukkan pada keterampilan menyelesaikan masalah kompleks. Hanya $70 \%$ dari total siswa yang dapat mencari solusi dari situasi yang diberikan. Hal ini dikarenakan siswa hanya terpaku pada rumus yang telah mereka ketahui. Mereka tidak menggabungkan konsepsi-konsepsi yang telah mereka punya sehingga masalah yang diberikan tidak terselesaikan dengan baik. Pemikiran seperti ini menandakan bahwa siswa masih tergolong pada taraf pemula (novice) karena tidak bisa menggabungkan semua konsepsi yang mereka punya untuk menyelesaikan masalah kompleks (Docktor \& Mestre, 2014).

Namun, secara keseluruhan, keterampilan berpikir kritis siswa pada kriteria kemampuan untuk bernalar, membuat keputusan dan menyelesaikan masalah, menguji hipotesis, menganalisis argument, serta menganalisis kemungkinan dan ketidakpastian telah meningkat setelah diberikan perlakukan menggunakan model pembelajaran bounded inquiry lab. Persentase keterampilan yang awalnya $22,00 \%$ pada saat pretest, meningkat menjadi $80,67 \%$ pada saat posttest.

Selanjutnya, data hasil pretest dan posttest keterampilan berpikir kritis pada ketiga materi dilakukan uji normalitas menggunakan Kolmorogorov-Smirnov. Hasil analisis menunjukkan nilai 0,654 $>0,05$ pada pretest dan 0,971 $>0,05$ pada posttest sehingga data pretest dan posttest yang didapatkan berasal dari populasi yang terdistribusi normal. Kemudian dilakukan pengujian untuk mengetahui ada atau tidaknya perbedaan nilai pretest dan posttest menggunakan paired sample t-test. Hasil pengujian menggunakan paired sampe t-test disajikan pada Tabel 3.

Berdasarkan hasil pengujian paired sample t-test, didapatkan nilai t sebesar -27,493 dengan besar sig. 0,000 . Hal ini menunjukkan bahwa terdapat perbedaan antara nilai pretest dan posttest pada keterampilan berpikir kritis siswa. Nilai negatif pada hasil perhitungan t menunjukkan bahwa nilai posttest lebih baik dari nilai pretest. Selanjutnya data pretest dan posttest digunakan untuk menghitung nilai gain ternormalisasi $<$ g $>$. Tabel 4 menyajikan rata-rata gain ternormalisasi $<\mathrm{g}>$ keterampilan berpikir kritis siswa dan kekuatan perbedaan nilai pretest dan posttest menggunakan perhitungan effect size (d). Nilai rata-rata gain ternormalisasi berada pada kategori tinggi $(0,75)$ dan kekuatan perbedaan nilai pretest dan posttest siswa berada pada kategori sangat besar $(5,80)$.

Tabel 3. Hasil analisis paired sample t-test dari nilai pretest dan posttest siswa

\begin{tabular}{ccccccc}
\hline $\mathbf{N}$ & $\bar{x}$ & SD & $\boldsymbol{\alpha}$ & Df & t & Sig. \\
\hline 30 & $-57,14$ & 11,76 & 0,05 & 29 & $-27,493$ & 0,000 \\
\hline
\end{tabular}

Tabel 4. Rata-rata nilai pretest-posttest, gain ternormalisasi $\langle\mathrm{g}\rangle$, dan effect size (d) keterampilan berpikir kritis siswa

\begin{tabular}{cccccc}
\hline \multicolumn{6}{c}{ Keterampilan berpikir kritis siswa } \\
\hline \multicolumn{2}{c}{ Rata-rata } & \multicolumn{2}{c}{ Gain ternormalisasi } & \multicolumn{2}{c}{ Effect size } \\
\hline Pretest & Posttest & $<$ g $>$ & Kriteria & D & Kriteria \\
\hline 22,00 & 80,67 & 0,75 & Tinggi & 5,80 & Sangat besar \\
\hline
\end{tabular}

Tabel 5. Tabulasi silang jawaban pretest dan posttest soal nomor 1.

\begin{tabular}{|c|c|c|c|c|c|c|c|}
\hline \multirow{7}{*}{ 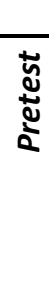 } & \multicolumn{7}{|c|}{ Posttest } \\
\hline & & A & B* & C & D & $E$ & Tot \\
\hline & A & 3 & 7 & & & & 10 \\
\hline & B* & & 5 & & & & 5 \\
\hline & C & 1 & 8 & & & & 9 \\
\hline & D & & 3 & & & & 3 \\
\hline & $\mathbf{E}$ & & 3 & & & & 3 \\
\hline
\end{tabular}




\begin{tabular}{cccc}
\hline Tot & 4 & 26 & 30 \\
\hline Keterangan: *Jawaban benar & &
\end{tabular}

Analisis kualitatif keterampilan berpikir kritis siswa dilakukan berdasarkan perubahan jawaban dari jawaban pretest ke posttest. Soal pada materi tekanan hidrostatis diambil sampel pada soal nomor 1 yaitu kemampuan bernalar untuk mendeskripsikan hubungan antar variabel pada tekanan hidrostatis. Tabulasi silang hasil jawaban pretest dan posttest siswa pada soal nomor 1 disajikan pada Tabel 5.

Berdasarkan Tabel 5, terdapat 7 siswa yang mulanya menjawab A pada pretest merubah jawabannya menjadi B saat posttest. Siswa tersebut beralasan tekanan terkecil berada pada titik yang mempunyai kedalam besar karena tekanan atmosfer yang dialaminya menjadi kecil. Miskonsepsi seperti ini seringkali timbul di pemikiran siswa (Besson, 2007; Goszewski, Moyer, Bazan, \& Wagner, 2012; Loverude, Heron, \& Kautz, 2013; Saifullah, Wartono, \& Sugiyanto, 2015). Namun, pada saat posttest, konsepsi tersebut diubah yaitu tekanan total yang dialami benda/ titik dipengaruhi oleh tekanan atmosfer dan tekanan hidrostatis. Semakin dalam posisi benda dalam zat cair, semakin besar pula tekanan total yang dialami karena bertambahnya nilai tekanan hidrostatis. Terdapat 8 siswa yang menjawab $C$ pada saat pretest dan merubah jawabannya menjadi B pada saat posttest. Mereka berpendapat bahwa tekanan terkecil berada pada volume yang besar. Semakin besar volume wadah, maka tekanan yang diterima benda/ titik semakin kecil. Miskonsepsi seperti ini sering dialami oleh siswa saat belajar tekanan hidrostatis (Besson, 2007; Goszewski, Moyer, Bazan, \& Wagner, 2012; Marlis, 2015).

Berdasarkan Tabel 5, terdapat 3 siswa yang menjawab D pada saat pretest dan menjawab B pada saat posttest. Mereka menjawab $\mathrm{D}$ karena tekanan terkecil akan dialami oleh titik/ benda pada wadah yang kecil, tanpa memperhatikan kedalaman. Konsepsi salah seperti ini juga sering terjadi pada siswa (Besson, 2007; Loverude, Heron, \& Kautz, 2013; Saifullah, Wartono, \& Sugiyanto, 2015). Namun setelah posttest, mereka mengubah konsepsi mereka dengan memperhatikan kedalaman dan tidak memperhatikan bentuk wadah sebagai variabel yang mempengaruhi tekanan hidrostatis. Terdapat 3 orang siswa yang sebelumnya menjawab E saat pretest dan berubah menjawab B pada saat posttest. Siswa tersebut menganggap tekanan hidrostatis dipengaruhi oleh volume dan bentuk wadah.

Soal pada materi hukum Pascal diambil sampel pada soal nomor 3 yaitu menganalisis argumen terkait penerapan hukum Pascal di kehidupan sehari-hari. Tabulasi silang hasil jawaban pretest dan posttest siswa pada soal nomor 3 disajikan pada Tabel 6. Berdasarkan Tabel 6, terdapat 7 siswa yang mulanya menjawab A pada pretest merubah jawabannya menjadi E saat posttest. Siswa tersebut beralasan semakin kecil ukuran pipa pada ruangan terbuka, maka semakin tinggi kenaikan air. Miskonsepsi seperti ini seringkali timbul di pemikiran siswa karena kurangnya pemahaman terkait persyaratan hukum Pascal (Sutarja, Sutopo, \& Latifah, 2016). Namun, pada saat posttest, konsepsi tersebut diubah yaitu semakin kecil ukuran pipa, semakin tinggi kenaikan air asalkan fluida (air) berada pada ruangan yang tertutup. Berdasarkan Tabel 6, terdapat 7 siswa yang menjawab $\mathrm{C}$ pada pretest dan merubah jawabannya menjadi $\mathrm{E}$ saat posttest. Siswa tersebut beralasan tekanan yang dihasilkan pada kedua ujung bejana tidak dipengaruhi oleh luas penampang. Namun, pada saat posttest, konsepsi tersebut diubah menjadi luas penampang mempengaruhi besarnya tekanan yang dihasilkan pada masing-masing penampang. Berdasarkan Tabel 6, terdapat 5 siswa yang menjawab D saat pretesttetapi merubah jawabannya menjadi E saat posttest. Siswa tersebut beralasan kenaikan piston semakin tinggi jika luas alas piston diperbesar. Miskonsepsi tersebut juga telah teridentifikasi oleh (Sutarja et al., 2016). Namun pada saat posttest, siswa merubah konsepsinya menjadi semakin kecil luas alas piston, maka semakin tinggi kenaikan piston. 
Tabel 6. Tabulasi silang jawaban pretest dan posttest soal nomor 3.

\begin{tabular}{|c|c|c|c|c|c|c|c|}
\hline \multirow{4}{*}{ 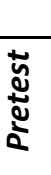 } & \multicolumn{7}{|c|}{ Posttest } \\
\hline & & A & B & C & D & $\mathrm{E}^{*}$ & Tot \\
\hline & A & & & & & 7 & 7 \\
\hline & B & & & 1 & & 1 & 2 \\
\hline & C & & 1 & & & 7 & 8 \\
\hline & D & & & & & 5 & 5 \\
\hline & $\mathrm{E}^{*}$ & & & 4 & & 4 & 8 \\
\hline & Tot & & 1 & 5 & & 24 & 30 \\
\hline
\end{tabular}

Keterangan: *Jawaban benar

Tabel 7. Tabulasi silang jawaban pretest dan posttest soal nomor 4.

\begin{tabular}{|c|c|c|c|c|c|c|c|}
\hline \multirow{4}{*}{ 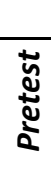 } & \multicolumn{7}{|c|}{ Posttest } \\
\hline & & $A$ & B & $\mathrm{C}$ & D* & $E$ & Tot \\
\hline & A & & & & 1 & & 1 \\
\hline & B & & 5 & & 7 & & 12 \\
\hline & C & & & & - & & \\
\hline & D* & & 4 & & 5 & & 9 \\
\hline & $E$ & & & & 8 & & 8 \\
\hline & Tot & & & & 21 & & 30 \\
\hline
\end{tabular}

Berdasarkan Tabel 7, terdapat 7 siswa yang menjawab B pada saat pretestdan merubah jawabannya menjadi $\mathrm{D}$ pada saat posttest. Mereka berpendapat bahwa gaya apung dari benda yang tenggelam seluruhnya meningkat seiring pertambahan kedalaman zat cair Miskonsepsi seperti ini sebelumnya telah ditemukan oleh (Wagner, Carbone, \& Lindow, 2013). Saat posttest, konsepsi siswa ini diubah menjadi kedalaman tidak mempengaruhi besar gaya apung yang dialami benda. Terdapat 5 orang yang sebelumnya menjawab E saat pretest dan berubah menjawab D saat posttest. Siswa telah merubah konsepsinya menjadi gaya apung dipengaruhi oleh volume benda, bukan massa benda yang tercelup.Miskonsepsi seperti ini sebelumnya juga telah ditemui oleh (Wagner et al., 2013).

\section{Simpulan}

Pengembangan keterampilan berpikir kritis membutuhkan suatu lingkungan yang aktif dan memfasilitasi siswa untuk membangun konsepsinya melalui kerja ilmiah. Bounded inquiry lab dapat menjadi salah satu alternatif strategi pembelajaran yang dapat digunakan untuk mengembangkan keterampilan berpikir kritis siswa yang meliputi keterampilan untuk bernalar, menguji hipotesis, menganalisis argumen, menganalisis kemungkinan dan ketidakpastian, serta keterampilan membuat keputusan dan menyelesaikan masalah kompleks. Keterampilan untuk bernalar dapat difasilitasi oleh guru melalui pembelajaran bounded inquiry lab pada tahap observasi terhadap fenomena-fenomena yang berkaitan dengan materi. Selain itu, bounded inquiry labjuga dapat memfasilitasi siswa agar mempunyai keterampilan menguji hipotesis melalui kegiatan menentukan variabel, menentukan hubungan antar variabel, membuat hipotesis, dan prosedur ilmiah. Prosedur ilmiah berupa rancangan percobaan yang dibuat oleh siswa dapat meningkatkan keterampilan menganalisis kemungkinan dan ketidakpastian. Menganalisis argumen dapat dilatihkan pada pembelajaran melalui kegiatan presentasi pada tahap ketiga bounded inquiry lab yaitu tahap generalisasi. Keterampilan membuat keputusan dan menyelesaikan masalah kompleks dapat dilatihkan oleh guru pada tahap terakhir bounded inquiry lab yaitu aplikasi.

Berdasarkan perbandingan nilai pretest dan posttest, terdapat perbedaan keterampilan berpikir kritis yang sangat besar $(d=5,80)$ sebelum dan sesudah pembelajaran. Persentase keterampilan berpikir kritis yang awalnya sebesar $20 \%$ meningkat menjadi $80,67 \%$ setelah pembelajaran dengan nilai $\mathrm{N}$-gain sebesar 0,75 (kategori tinggi). 
Keterbatasan dari penelitian ini adalah jumlah soal dan jumlah subyek penelitian yang tidak terlalu banyak sehingga diharapkan penelitian selanjutnya dapat menggunakan lebih banyak soal keterampilan berpikir kritis dan subyek penelitian.

\section{Daftar Rujukan}

Alwehaibi, H. U., Noura, P., Abdulrahman, B., Arabia, S., Noura, P., \& Abdulrahman, B. (2012). Novel Program to Promote Critical Thinking among Higher Education Students : Empirical Study from Saudi Arabia, 8(11), 193-204. https://doi.org/10.5539/ass.v8n11p193

Anderson, T., Howe, C., Soden, R., \& Low, J. (2001). Peer interaction and the learning of critical thinking skills in further education students, 1-32.

Angeli, C., \& Valanides, N. (2009). Instructional effects on critical thinking : Performance on ill-defined issues. Learning and Instruction, 19(4), 322-334. https://doi.org/10.1016/j.learninstruc.2008.06.010

Arum, R., \& Roksa, J. (2011). Limited Learning on College Campuses, 203-207. https://doi.org/10.1007/s12115-011-9417-8

Barnett, J. E., \& Francis, A. L. (2012). Educational Psychology : An International Journal of Experimental Using higher order thinking questions to foster critical thinking : a classroom study, (April 2013), 3741.

Bensley, D. A., Crowe, D. S., Bernhardt, P., Buckner, C., Amanda, L., Bensley, D. A., Allman, A. L. (2010). Teaching of Psychology Teaching and Assessing Critical Thinking Skills for Argument Analysis in Psychology Teaching and Assessing Critical Thinking Skills for Argument Analysis in Psychology, (January 2015), 37-41. https://doi.org/10.1080/00986281003626656

Bensley, D. A., \& Spero, R. A. (2014). Improving critical thinking skills and metacognitive monitoring through direct infusion. Thinking Skills and Creativity, 12, 55-68. https://doi.org/10.1016/j.tsc.2014.02.001

Besson, U. (2007). International Journal of Science Students ' conceptions of fluids, (November 2014), 3741. https://doi.org/10.1080/0950069042000243745

Butler, H. A., Dwyer, C. P., Hogan, M. J., Franco, A., Rivas, S. F., Saiz, C., \& Almeida, L. S. (2012). The Halpern Critical Thinking Assessment and real-world outcomes : Cross-national applications $\Xi$ Thinking Skills and Creativity, 7(2), 112-121. https://doi.org/10.1016/j.tsc.2012.04.001

Creswell, J., Clark, V. (2007). Designing and Conducting Mixed Method Research. California: Sage Publication, Inc.

Docktor, J. L., \& Mestre, J. P. (2014). Synthesis of discipline-based education research in physics, 020119, 158. https://doi.org/10.1103/PhysRevSTPER.10.020119

Dwyer, C. P., Hogan, M. J., \& Stewart, I. (2012). An evaluation of argument mapping as a method of enhancing critical thinking performance in e-learning environments, 219-244. https://doi.org/10.1007/s11409-012-9092-1

Goszewski, M., Moyer, A., Bazan, Z., \& Wagner, D. J. (2012). Exploring Student Difficulties with Pressure in a Fluid, 7-10.

Halpern, D. F. (2014). Thought and Knowledge: An Introduction to Critical Thinking (fifth edit). Psychology Press.

Holmes, N. G. (2017). Toolboxes and handing students a hammer : The effects of cueing and instruction on getting students to think critically, 010116, 1-13. https://doi.org/10.1103/PhysRevPhysEducRes.13.010116

Ku, K. Y. L., Ho, I. T., \& Eva, K. H. (2014). Integrating direct and inquiry-based instruction in the teaching of critical thinking : an intervention study, 251-269. https://doi.org/10.1007/s11251-013-9279-0

Lasry, N., Charles, E., \& Whittaker, C. (2014). When teacher-centered instructors are assigned to studentcentered classrooms, 010116, 1-9. https://doi.org/10.1103/PhysRevSTPER.10.010116

Loverude, M. E., Heron, P. R. L., \& Kautz, C. H. (2013). Identifying and addressing student difficulties with hydrostatic pressure Identifying and addressing student difficulties with hydrostatic pressure, 75(2010). https://doi.org/10.1119/1.3192767

Marlis. (2015). Analisis Profil Pemahaman Konsep dan Konsistensi Konsepsi Siswa Kelas X SMA Negeri 1 Tilatang Kamang pada Materi Fluida Statis, 2015(Snips), 413-416. 
Mazer, J., Hunt, S., \& Kuznekoff, J. (2008). Revising General Education: Assessing A Critical Thinking Instructional Model In The Basic Communication Course. The Journal of General Education, 56(3/4), 173-199. Retrieved from http://www.jstor.org/stable/27798079

Mclean, C. P., Miller, N. A., Mclean, C. P., \& Miller, N. A. (2010). Teaching of Psychology Changes in Critical Thinking Skills Following a Course on Science and Pseudoscience : A Quasi-Experimental Study Changes in Critical Thinking Skills Following a Course on Science and Pseudoscience : A QuasiExperimental Study, (February 2015), 37-41. https://doi.org/10.1080/00986281003626714

Merrill, M. D. (2013). First Principles of Instruction: Identifying and Designing Effective, Efficient, and Engaging Instruction. Pfeiffer.

Odabas, H. F. (2009). Computers \& Education Effects of an online problem based learning course on content knowledge acquisition and critical thinking skills q, 53, 132-141. https://doi.org/10.1016/j.compedu.2009.01.008

Of, E., Thinking, C., In, I., \& Education, H. (2014). Effectiveness of critical thinking instruction in higher education : A systematic review of intervention studies, 9-44.

Pascarella, E. T. (2016). How College Affects Students : Ten Directions for Future Research, 47(5), 508-520. https://doi.org/10.1353/csd.2006.0060

Piergiovanni, P. R., \& Piergiovanni, P. R. (2014). Creating a Critical Thinker Creating a Critical Thinker, (October), 37-41. https://doi.org/10.1080/87567555.2014.896775

Preiss, D. D., \& Sternberg, R. J. (Eds.). (2010). Innovations in Educational Psychology: Perspectives on Learning, Teaching, and Human Development. Springer Publishing Company.

Ramsey, B. K., \& Baethe, B. (2013). The Keys to Future STEM Careers : Basic Skills, Critical Thinking, and Ethics, 26-34.

Renaud, R. D., \& Murray, H. G. (2008). A comparison of a subject-specific and a general measure of critical thinking, 3, 85-93. https://doi.org/10.1016/j.tsc.2008.03.005

Saifullah, A. M., Wartono, \& Sugiyanto. (2015). Pengembangan instrumen diagnostik.

Solon, T. (2007). This is the 2006 AILACT Essay prize winning paper. The official published version appears in, 34(2), 95-109.

Sutarja, M. C., Sutopo, \& Latifah, E. (2016). Identifikasi Kesulitan Pemahaman Konsep Siswa pada Fluida Statis. Pros. Semnas Pend. IPA Pascasarjana UM.

Tiruneh, D. T., \& Cock, M. De. (2017). Measuring Critical Thinking in Physics : Development and Validation of a Critical Thinking Test in Electricity and Magnetism, 663-682. https://doi.org/10.1007/s10763-0169723-0

Tiruneh, D. T., Verburgh, A., \& Elen, J. (2014). Effectiveness of Critical Thinking Instruction in Higher Education : A Systematic Review of Intervention Studies, 4(1). https://doi.org/10.5539/hes.v4n1p1

Tiruneh, D. T., Weldeslassie, A. G., Kassa, A., Tefera, Z., Cock, M., \& Elen, J. (2016). specific and domaingeneral critical thinking skills. Educational Technology Research and Development, 64(3), 481-505. https://doi.org/10.1007/s11423-015-9417-2

Toy, B. Y., \& Ok, A. (2012). European Journal of Teacher Education Incorporating critical thinking in the pedagogical content of a teacher education programme : does it make a difference ?, (August 2013), 37-41. https://doi.org/10.1080/02619768.2011.634902

Wagner, D. J., Carbone, E., \& Lindow, A. (2013). Exploring Student Difficulties with Buoyancy, (may), 357360. https://doi.org/10.1119/perc.2013.pr.077

Wenning, C. J. (2010). The Changing Nature of Journal of Physics Teacher Education Online. Journal Of Physics Teacher Education Online, 5(4). Retrieved from www.phy.ilstu.edu/jpteo

Wenning, C. J. (2011). A New Model for Science Teaching. Journal Of Physics Teacher Education Online, 6(2). Retrieved from www.phy.ilstu.edu/jpteo/

Yeh, Y. (2009). Integrating e-learning into the Direct-instruction Model to enhance the effectiveness of critical-thinking instruction, 185-203. https://doi.org/10.1007/s11251-007-9048-z

Young, D. E., College, G. A., \& Peter, S. (2017). Using the resources framework to design, assess, and refine interventions on pressure in fluids, 010125, 1-16.

https://doi.org/10.1103/PhysRevPhysEducRes.13.010125 